University at Albany, State University of New York

Scholars Archive

5-19-2015

\title{
Go Team! Using Teams to Manage Electronic Resources
}

Rebecca A. Nous

University at Albany, State University of New York, rnous@albany.edu

Wendy L. West

University at Albany, State University of New York, wwest@albany.edu

Follow this and additional works at: https://scholarsarchive.library.albany.edu/ulib_fac_scholar

Part of the Library and Information Science Commons

\section{Recommended Citation}

Nous, Rebecca \& Wendy West. "Go team! Using teams to manage electronic resources." Binghamton University: Eastern New York Chapter of the Association of College \& Research Libraries Spring Conference. Poster session. May 19, 2015.

This Other is brought to you for free and open access by the University Libraries at Scholars Archive. It has been accepted for inclusion in University Libraries Faculty Scholarship by an authorized administrator of Scholars Archive. For more information, please contact scholarsarchive@albany.edu. 


\section{GO TEAM!}

\section{Using Teams to Manage Electronic Resources}

The increasing prevalence of electronic journals in library collections has impacted many aspects of library operations. Libraries have had to rethink workflows, processes, staffing needs, and other factors to account for the differences between print and online journals. The management of electronic journals can often cross departmental boundaries and bring into question current workflow. To address the changing landscape of electronic journal management, the University at Albany University Libraries developed two teams: one to implement batchloading electronic journal records and a second to address ongoing management and related policies. As a result of using a team approach for these responsibilities, the University Libraries was able to streamline processes, reduce duplication of effort across departments, coordinate policies and procedures, improve communication, and develop best practices.

\section{MARC Implementation Team}

This team was charged with transitioning from a manual process for maintaining electronic journal access to batchloading electronic journal bibliographic records. This team was responsible for creating a record profile with our vendor, developing an implementation timeline, testing the process, and performing the initial batchloads in the production side of our ILS.

\section{Electronic Resources Management Team}

This team was charged with coordinating the management of electronic resources, documenting and assessing workflows, and making

recommendations for improving electronic resource management And to ensure that policies, practices, and decisions are made in a consistent manner.
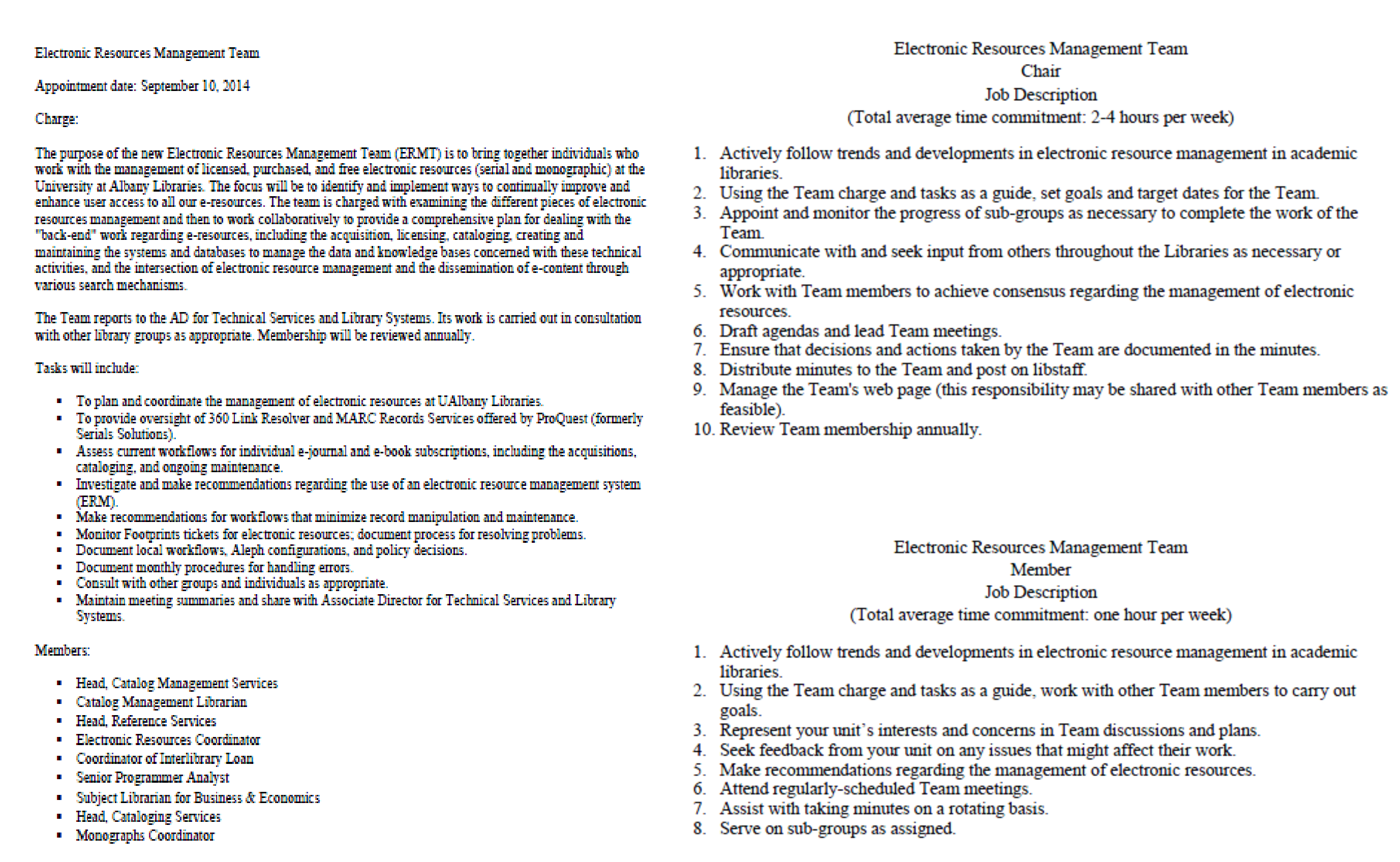

\section{Benefits}

- Smooth transition when changing processes

- Leverage the expertise and experience of each of the members/departments

Open lines of communication and increase awareness of the entire workflow throughout Technical Services

- Increased profile of the work of

Technical Services and Library Systems outside of the division

\section{Challenges}

- $\quad$ Large learning curve for some members

- $\quad$ More deliberative, slower process

- Sometimes difficult to reach consensus

- Difficulty finding times to schedule meeting times that worked for everyone

\section{Lessons}

- Need for good communication

- Open sharing of information speeds problem resolution

- A project management tool would help to keep everyone on the same page

- Team composition is a key component for success

- It's important to deal with data clean-up as soon as possible to avoid legacy data issues later on 